日本臨床麻酔学会第 26 回大会パネルディスカッション

硬膜外麻酔で作用時間の異なる局所麻酔薬をどのように使うか ?

硬膜外麻酔に用いる局所麻酔薬の特徵

横山正尚*

\begin{abstract}
[要旨] 多くの局所麻酔薬のなかから硬膜外麻酔の用途に応じて薬剤を選択すること は理想である。しかし, 心毒性, 神経毒性などが明らかとなり, 危険性の少ない薬剤 が登場した今, 安全性は第一に考慮される選択基準である.さらに局所麻酔薬の効果 の増強目的でさまざまな薬剤の添加が報告されているが, 効果と副作用のバランスを 考慮した場合，その選択はごく限られる．また，医療経済および事故防止の面から多 種の同効薬刘を使用することは問題となりうる. その意味ではテスト注入に短時間作 用性の薬剤を使用し, そのほかには安全性の高い局所麻酔薬を選択し, 用途に応じた 濃度を使用すべきと思われる. キーワード：局所麻酔薬, 作用時間, 硬膜外麻酔
\end{abstract}

（日臨麻会誌 Vol.27 No.5, $445 ４ 55,2007$ )

\section{はじめに}

術中管理の利点, 周術期合併症の軽減ならびに術 後鎮痛に優れているなどのエビデンスより，硬膜外 麻酔が単独，あるいは春髄くも膜下麻酔や全身麻酔 との併用という形で麻酔法の主流となってきた。硬 膜外麻酔が盛んになるなか, 局所麻酔薬は安全性の 問題で新しい時代に入ってきた。多くの局所麻酔薬 が使用できるが，その特徵を十分に理解し，使い分 けているかは疑問である。言い換えれば，安全で使 用しやすい局所麻酔薬のみをうまく使いこなせば, 多くの種類は必要ないのかもしれない.

局所麻酔薬本来の効力や作用時間に変化をもたら そうと多くの試みがなされてきた。迅速な作用発現， 効果の増強，そして持続時間の延長などを期待して
さまざまな薬剤が局所麻酔薬に添加されている。た だし，このことは利点だけではなく，神経障害をは じめ局所麻酔薬の毒性が注目されている現在では注 意を要する問題でもある.

心毒性でブピバカインの使用が敬遠され ${ }^{1), 2)}$ ，長 時間作用性としてロピバカイン，レボブピバカイン が開発された ${ }^{3)}$. 短時間作用性のリドカインはtransient neurologic symptomsの問題で4), 少なくとも 脊髄くも膜下麻酔に使用されることはなくなった。 硬膜外麻酔にどの薬剤を使用すべきなのかは，安全 性のほかにも多くの課題がある。例えば，医療経済 的観点は現在では最も重要な薬剤選択基準の一つで あり，多種の同効薬剤は業務上の混乱の原因にもな りかねない，そのような観点もふまえて，硬膜外麻酔 に使用する局所麻酔薬の基礎と臨床を概説する。
*岡山大学大学院医歯薬学総合研究科 麻酔・蘇生学分野
著者連絡先 横山正尚

T 700-8558 岡山市鹿田町 2-5-1

岡山大学大学院医歯薬学総合研究科 麻酔・蘇生学分野 


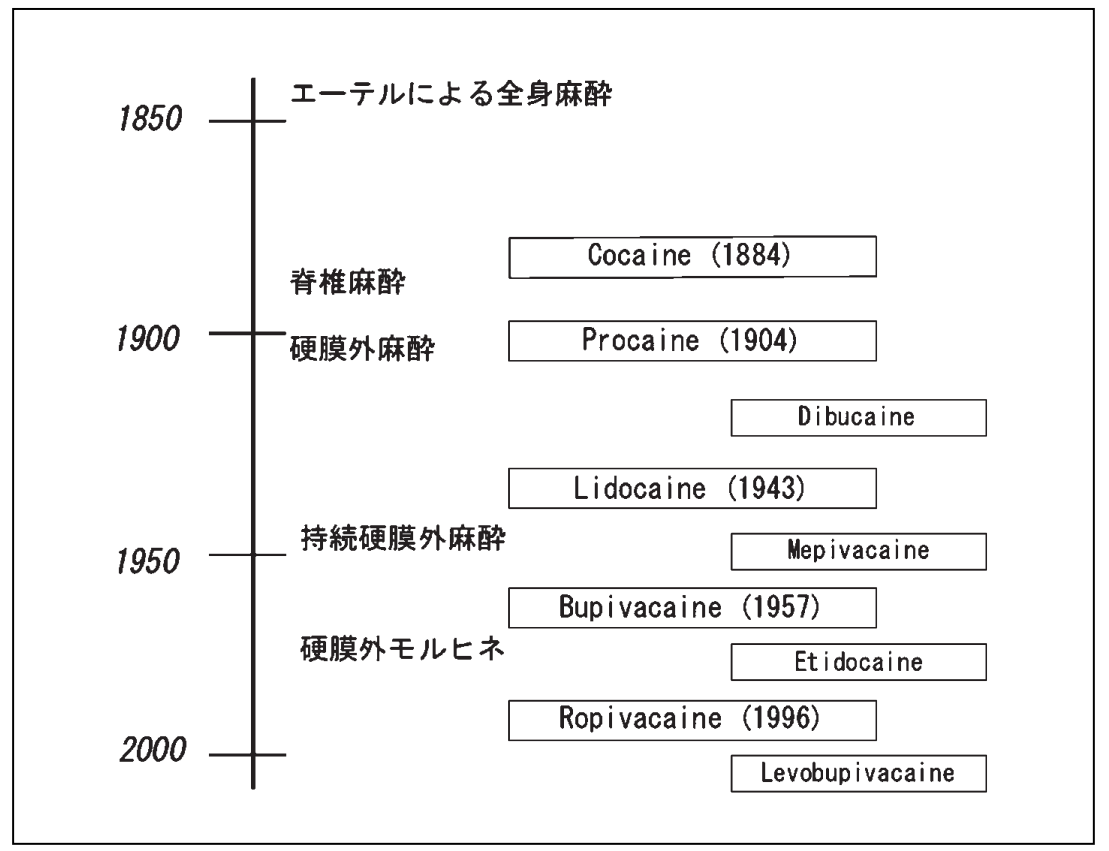

図1 局所麻酔薬の歴史

\section{I 歴史}

歴史的にみると，硬膜外麻酔の実質的な開始から 約 100 年が経過している(図1)。プロカインが合成 されたのが約 100 年ほど前で, 硬膜外麻酔の歴史は 局所麻酔薬の歴史と重㸚られる。当初は単回投与に よる硬膜外麻酔のみであったが，1950年頃に持続硬 膜外カテーテルが臨床応用され始めたことが，硬膜 外麻酔の一般的普及に大きな影響を及ぼしたと考え られる。ささに，現在でも最もポピュラーな短・中 時間作用性局所麻酔薬としてリドカインが開発され たのが1943年である。この薬剤の登場により, 従来 に比べ局所麻酔法そのものが大きく改善された。 1957 年には長時間作用性局所麻酔薬としてブピバカ インが登場し, 長らく硬膜外麻酔に使用される薬剤 の代表として扱われてきた。しかし，ブピバカイン による重篤な心毒性が報告され ${ }^{1), 2}$, 毒性の少ない 長時間作用性局所麻酔薬としてロピバカインが開発 されると ${ }^{3,5)}$, ブピバカインの使用は激減した観が ある。また，ブピバカインの安全性を高めようとす
る努力はレボブピバカインの開発にも向けられ, 日 本では現在治験中である.

\section{II 局所麻酔薬の物理化学的特徵と効果}

\section{1. 蛋白結合力}

局所麻酔薬の主な作用機序はイオンチャネルのブ ロックと考えられる。神経膜のイオンチャネルは蛋 白より構成されている。蛋白結合力の強い局所麻酔 薬はイオンチャネルに強く結合すると考えられ，神 経ブロックの強さと効果時間に関係する (表 1) ${ }^{6}$.

\section{2. 脂溶性}

局所麻酔薬は神経膜に浸潤して作用を発揮する。 その神経膜は脂質より成り立っており，脂溶性が局 所麻酔薬の神経膜への浸潤に大きく影響し，効果時 間および作用発現時間に関係すると考えられる(表1)。

\section{3. $\mathrm{pKa}$}

局所麻酔薬は溶液中で帯電した陽イオンと，帯電 していない塩基に解離している $(\text { 図 } 2 A)^{7}$ )。解離の程 度は図2Aの式で示されるように, 局所麻酔薬固有 の $\mathrm{pKa}$ と周囲組織の $\mathrm{pH}$ によ規定される。局所麻 
表 1 局所麻酔薬の効果と物理化学的性質

\begin{tabular}{lccccccc}
\hline 薬剤 & 持続時間 & 効力 & 発現時間 & 毒性 & 蛋白結合力 & 脂溶性 & $\mathrm{pKa}$ \\
\hline Procaine & 1 & 1 & 早 & 1 & 5.8 & 0.6 & 8.9 \\
Chloroprocaine & 0.75 & 4 & 早 & $0.5 \sim 1$ & & & 8.7 \\
Lidocaine & 1.5 & 4 & 早 & $1 \sim 1.5$ & 64 & 2.9 & 7.7 \\
Mepivacaine & 1.5 & 2 & 早 & $1 \sim 2$ & 77 & 1.0 & 7.6 \\
Bupivacaine & 8 & 16 & 遅 & $4 \sim 6$ & 95 & 28 & 8.1 \\
Etidocaine & 8 & 16 & 早 & $1.5 \sim 4$ & 94 & 141 & 7.7 \\
\hline
\end{tabular}

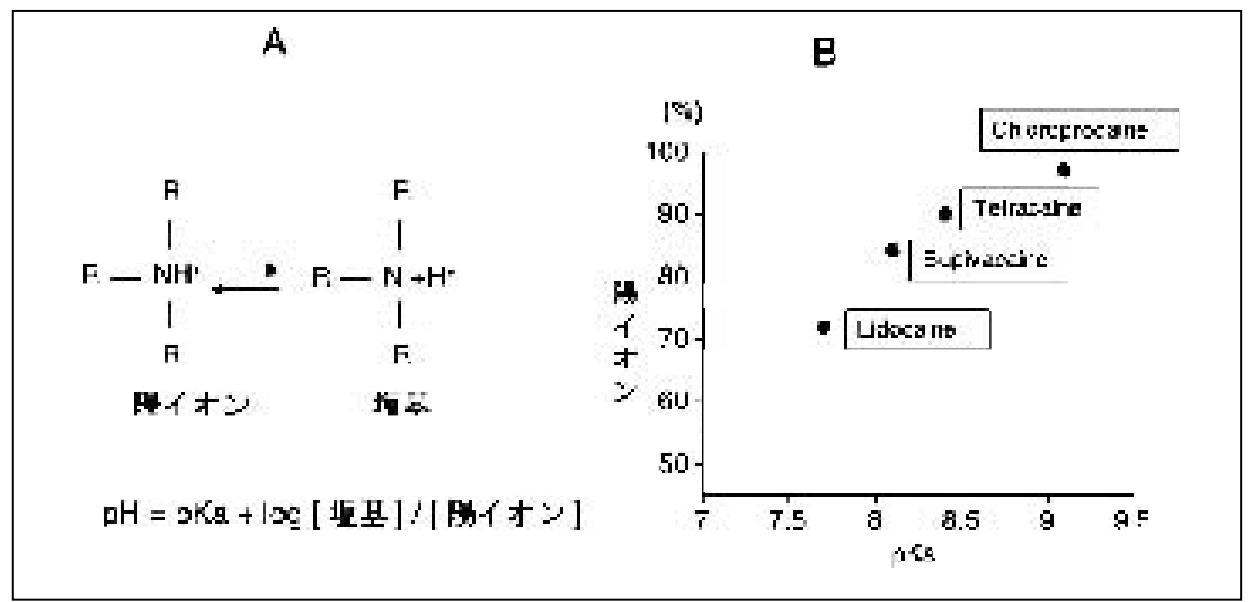

図 2 局所麻酔薬の解離状態 $(\mathrm{A})$ と $\mathrm{pH} 7.4$ における各種局所麻酔薬の陽イオンの占める 割合(B)

酔薬の作用の本態は陽イオンにより, 塩基は神経膜 の透過の役割を担っている。図2BはpH7.4におけ る各種局所麻酔薬の解離の程度を示しているが，低 い pKa 群は高い pKa 群に比べて陽イオンが少なく (塩基が多く)，作用発現が早くなる。

\section{4. 血管拡張作用}

ほとんどの局所麻酔薬は血管平滑筋に対して 2 相 性の反応を示す ${ }^{8), 9)}$. すなわち，ごく低濃度では血 管収縮作用を示すが，臨床使用濃度では血管拡張作 用を示す。新しい長時間作用性局所麻酔薬のロピバ カインは，臨床使用濃度で血管収縮作用というユニ ークな性質を有している ${ }^{10)}$. 血管拡張作用の強弱は 組織からの吸収の速度に影響し, 局所麻酔薬の血中 濃度および効果持続時間に影響を及ぼす。

\section{5. 選択的神経ブロック}

局所麻酔薬の臨床使用で知覚神経と運動神経の分 離遮断は重要な意味をもつ. ある種の局所麻酔薬は, 適切な濃度を用いれば，知覚神経を強く遮断し，運 動神経の遮断を最小限にすることが可能である。硬 膜外麻酔ではブピバカインおよびロピバカインは選 択的神経ブロックが得られやすく，術後鎮痛やペイ ンクリニックでの使用に適していると考えられる ${ }^{11}$.

\section{6. 毒性}

一般的には代謝・分解が速やかな局所麻酔薬は毒 性が少ない(表 1)。高濃度使用は物理化学的に神経 や筋組織への毒性を生じる可能性がある ${ }^{12)}$. ブピバ カインの心毒性などで注目されたが，ラセミ体 (左・右旋性光学異性体混合) は毒性が強く, 左旋性 のみでは毒性が低くなることが知られており，ロピ 
表2 局所麻醉薬の効果発現時間と持続時間

\begin{tabular}{|c|c|c|c|c|}
\hline \multirow[b]{2}{*}{ 薬剂 } & \multirow[b]{2}{*}{ 濃度 (\%) } & \multirow[b]{2}{*}{ 発現時間 (min) } & \multicolumn{2}{|c|}{ 持続時間 (min) } \\
\hline & & & 単独 & 1 1:200,000 エピネフリン \\
\hline 2-Chloroprocaine & 3 & $10 \sim 15$ & $45 \sim 60$ & $60 \sim 90$ \\
\hline Lidocaine & 2 & 15 & $80 \sim 120$ & $120 \sim 180$ \\
\hline Mepivacaine & 2 & 15 & $90 \sim 140$ & $140 \sim 200$ \\
\hline Bupivacaine & $0.5 \sim 0.75$ & 20 & $165 \sim 225$ & $180 \sim 240$ \\
\hline Etidocaine & 1 & 15 & $120 \sim 200$ & $150 \sim 225$ \\
\hline Ropivacaine & $0.75 \sim 1.0$ & $15 \sim 20$ & $140 \sim 180$ & $150 \sim 200$ \\
\hline Levobupivacaine & $0.5 \sim 0.75$ & $15 \sim 20$ & $150 \sim 225$ & $150 \sim 240$ \\
\hline
\end{tabular}

バカインやレボブピバカインが開発されることとな つた ${ }^{3)}$.

\section{III 各種薬剤の特徵}

ほとんどの局所麻酔薬は硬膜外麻酔に使用するこ とができるが, 効果や毒性の問題のために実際に使 用される薬剤は限られる。以下に各薬剤の特徵をま とめる(表2) ${ }^{13)}$.

\section{1. クロロプロカイン}

分解がきわめて速やかで，毒性が少ない，発現時 間は速いが，持続時間が短い.エステルタイプであ り悪性高熱時の使用が可能である。硬膜外麻酔では $2 \%$ の濃度を使用する。

\section{2. リドカイン}

短・中時間作用性局所麻酔薬のプロトタイプ。持 続時間は $80 \sim 120$ 分程度でエピネフリン添加で 150 分程度に延長する. 知覚神経遮断には $0.5 \sim 1 \%$, 運 動神経遮断では $2 \%$ 程度を使用する。

\section{3.メピバカイン}

効力, 発現時間はリドカインとほぼ同じで, 持続 時間はやや長い。胎盤通過作用がリドカインより大 きく, 産科麻酔には適さない. 血管拡張作用が弱く, エピネフリンの添加でも作用時間の延長効果は少ない.

\section{4. プリロカイン}

急速に代謝され毒性が低い. 効力はリドカインと ほぼ同等で，作用発現時間はやや遅く, 持続時間は
短い.メトへモグロビン血症を引き起こす可能性が ある。硬膜外麻酔では 2 3\%で使用する。

\section{5. ブピバカイン}

長時間作用性局所麻酔として長らく主役を演じて きた．効力はリドカインより数倍強い．蛋白結合力 は最も長く，作用時間が長いが，効果発現は遅い. 知覚神経遮断の選択性があり, 疼痛治療に優れてい る。心毒性が問題となり, 特に高濃度での産科麻酔 への使用は制限されている。硬膜外麻酔において $0.125 \sim 0.25 \%$ の濃度での使用で選択的ブロックが可 能. $0.5 \%$ 使用で運動神経も遮断され，手術目的で使 用する。

\section{6. ロピバカイン}

ブピバカインの心毒性の問題より開発された新し い長時間作用性局所麻酔薬で, 安全性が高い.ブピ バカインとほぼ同等の効力. 血管収縮作用を有する. 知覚神経選択遮断に優れており, 硬膜外持続鎮痛の 主役となる．硬膜外麻酔では $0.2 \%$ 濃度で鎮痛作用 を示し，0.5〜 1\%の濃度で手術麻酔に使用する。

\section{7.レボブピバカイン}

左および右旋性混合 (ラセミ体) ブピバカインの心 毒性の問題解決のため, 左旋性光学異性体のみの開 発により登場した。日本では現在治験中、ロピバカ インと特徵はほぼ同様と考えられる。 $0.125 〜 0.25 \%$ の濃度使用で鎮痛， $0.5 \sim 0.75 \%$ の濃度で手術麻酔に 使用する。 


\section{8. エチドカイン}

長時間作用性であるが，ブピバカインよりやや短 い. 運動神経遮断作用が強く, 知覚神経の回復がよ り速く, 疼痛治療には不適。発現時間はブピバカイ ンよりやや早めである.

\section{9. ジブカイン}

毒性が強く大量使用できず，硬膜外麻酔には使用 しない.

\section{IV＼cjkstart臨床効果への影響因子}

\section{1. 容量および濃度}

用量 $($ 容量 : volume $\times$ 濃度 : concentration)を増 すと一般的には神経遮断作用の効力が増し, 発現時 間を速める。容量が同じであれば，当然濃度の高い 薬剂を使用した場合の方が，発現時間の短縮，効力 の増強，持続時間の延長が期待できる。用量を一定 とした場合, 容量と濃度のどちらの要因が硬膜外麻 酔に強く影響するのかよく問題となる。使用する容 量によっても結果は異なる可能性があるが, 例えば $1 \% 30 \mathrm{~m} l$ のリドカインあるいは $3 \% 10 \mathrm{~m} l$ のリドカイ ンを使用した場合, 硬膜外麻酔の無痛域の比較では, 前者の方が 4.3 分節広い無痛域を得たと報告されて いる ${ }^{14)}$. ある一定以上の濃度では, 無痛域の拡がり の点では容量の影響が大きいと思われる。

\section{2. 血管収縮薬の添加}

1/20万エピネフリンの添加は, 局所麻酔薬の効力 の増強，持続時間の延長，血中濃度を低下させるな どいくつかの利点がある。エピネフリンの効果はリ ドカインなどの短時間作用性局所麻酔薬で強く, ブ ピバカインやエチドカインではその効果は少ない (表2)。しかし血管収縮薬添加の局所麻酔薬を血管 内誤注した場合，痤攣などの中毒閾值を低下させる ので注意を要する(図3 $)^{15)}$.ノルエピネフリンやフ エニレフリンなど他の血管収縮薬には，エピネフリ ンより優れた点は認められない ${ }^{16)}$.

\section{3. 炭酸化と $\mathrm{pH}$ の調整}

抽出標本では二酸化炭素の局所麻酔薬溶液への添加

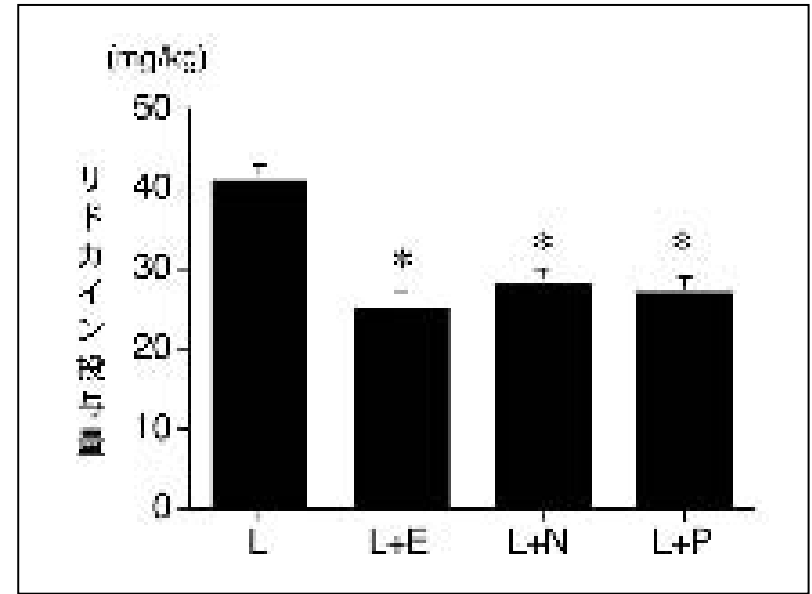

図３＼cjkstart血管収縮薬添加のリドカイン血管内詔注による痙 攣閾値に及ぼす影響

ラットの血管内誤注モデルにおいて, リドカイン $(\mathrm{L})$ 単独に比べてエピネフリン $(\mathrm{L}+\mathrm{E})$, ノルエピネフリ ン $(\mathrm{L}+\mathrm{N})$, あるいはフェニレフリン $(\mathrm{L}+\mathrm{P})$ の添加は 有意に痤攣誘発量を低下させる。

Values are mean $\pm \mathrm{SD}$, 各群 $\mathrm{n}=12,{ }^{*} \mathrm{P}<0.05$ vs. $\mathrm{L}$ 〔文献15)より引用・改変〕

は作用発現時間の短縮および効力の増加を示す ${ }^{17), 18)}$. しかし，臨床使用での局所麻酔薬の二酸化炭素の添 加の作用発現時間への影響には議論がある。ある報 告では硬膜外麻酔使用では塩酸リドカインと炭酸リ ドカインの作用発現時間に有意差は認めなかったと されるが19)，他の報告では炭酸リドカインで発現時 間が有意に短縮できたとしている ${ }^{20)} . \mathrm{NaHCO}_{3}$ の添 加も同様に作用発現を短縮することが報告されてい $3^{21,222}$. 局所麻酔薬のアルカリ化による $\mathrm{pH}$ の上昇 は塩基型局所麻酔の比率を増加させ，神経膜の透過 速度を高める。いくつかの報告ではリドカインおよ びブピバカインのアルカリ化は硬膜外麻酔の作用発 現時間の短縮をきたすとしているが21,22)，一方で否 定的な報告もある ${ }^{23)}$. 各報告の測定条件の違いによ ると思われる。

\section{4. その他の薬剤の添加}

局所麻酔薬にフェンタニルを添加した溶液を持続 注入することが術後鎮痛法として一般化している が，そのほかにもケタミン，クロニジンなど多くの 


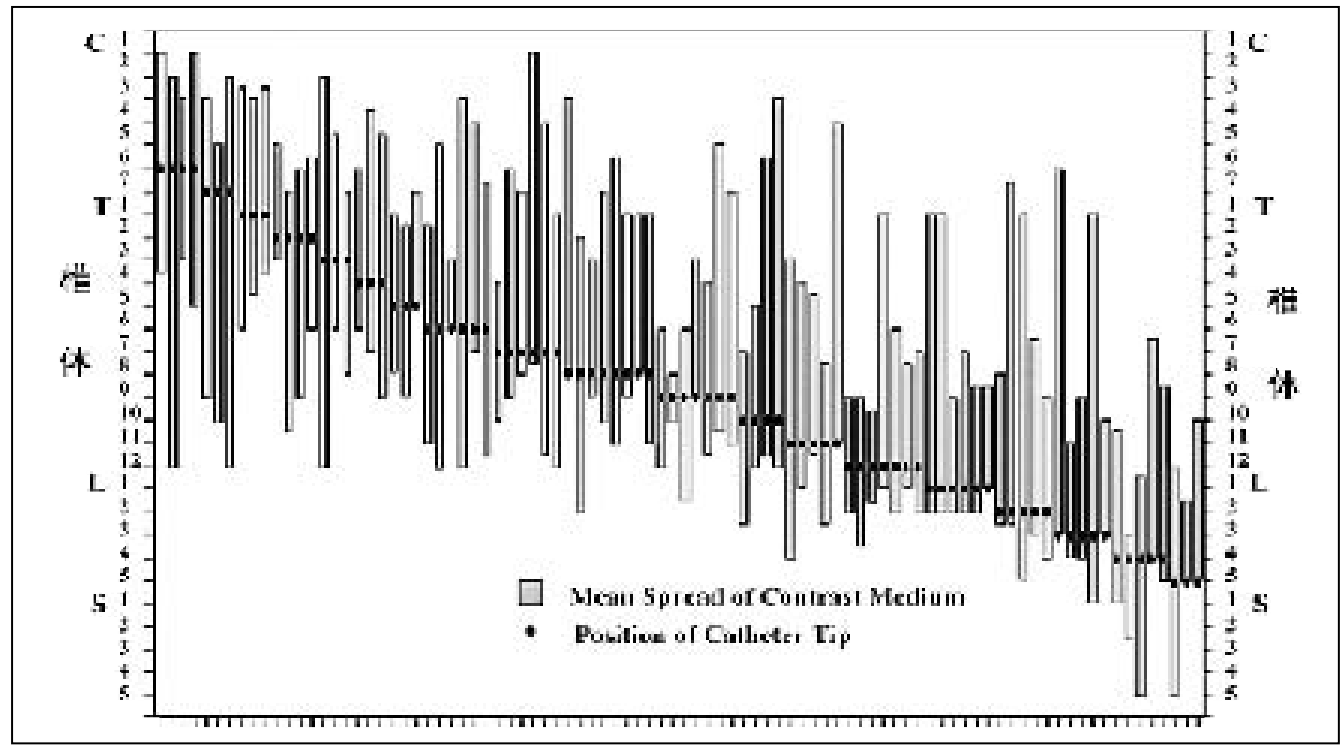

図4 硬膜外造影の拡がりとカテーテルの先端位置

イオトロラン $240 \mathrm{mg} \mathrm{I} / \mathrm{m} l$ を $5 \mathrm{~m} l$ 硬膜外注入した際の頭側および尾側への造影剤の拡がり. 造 影剤の拡がりは左右の平均で示す。黒丸は硬膜外カテーテルの先端位置を示す.

$\mathrm{C}$ : 頸椎, $\mathrm{T}$ : 胸椎, $\mathrm{L}$ : 腰椎, $\mathrm{S}$ : 仙椎. $\mathrm{n}=90$ 〔文献29)より引用・改変〕

薬剂添加による作用時間の延長あるいは効力増強が 報告されている ${ }^{24)}$. 疼痛の機序解明の観点からは興 味深いが，それらの効果と副作用および安全性を考 えた場合, エピネフリンやオピオイドに比べてその 臨床的意義は少ないと考えられる。

\section{5. 局所麻酔薬の混合}

発現時間の速い短時間作用性局所麻酔薬と持続時 間の長い長時間作用性局所麻酔薬を混合して両者の 長所を得ようとする試みがなされるが，硬膜外麻酔 では否定的である。例えばクロロプロカインとブピ バカインの混合では，作用発現時間はクロロプロカ イン単独よりも遅く, 作用持続時間はブピバカイン 単独よりも短い25)。 また，それぞれの局所麻酔薬の 極量まで使用可能で, 単独より多量の局所麻酔薬が 使用できるとの考えは䛊っており, 局所麻酔薬の毒 性は相加的と考えるべきである ${ }^{26)}$.

\section{6. 妊娠}

妊娠により硬膜外麻酔の効力が強くなり, 無痛域 も広くなる。この事実は妊娠後期のみでなく初期よ りみられることから, 単に硬膜外腔の解剖学的変化
だけではなく，ホルモンの変化の影響が大きいこと が示唆されている ${ }^{27)}$.すなわち妊娠によりホルモン の影響で局所麻酔薬の感受性が増加することが認め られる ${ }^{28)}$. 妊娠中は局所麻酔薬の投与量を減少させ るべきであり, 特に高濃度のブピバカインは局所麻 酔薬中毒の危険性を高める。

\section{7. 注入部位}

局所麻酔薬の血中濃度が注入部位によって異なる ことはよく知られているが，硬膜外麻酔でも部位に より局所麻酔薬の拡がりが異なり，血中濃度に影響 を与える可能性がある。この拡がりの違いは個人差 も大きく，予測が困難である $(\text { 図 4 })^{29}$ 。 また，手術 中に持続注入を施行したときの血中濃度を調べた研 究では, 肝切除術では時間の経過とともに血中濃度 が上昇する可能性があり, 注意が必要である(図 5 ${ }^{30}$.

\section{V 硬膜外麻酔に何を期待するか}

\section{1. 局所麻酔薬の選択に影響を及ぼす因子}

1) 全身麻酔併用か単独か

例えば下腹部手術を硬膜外麻酔単独で施行する場 


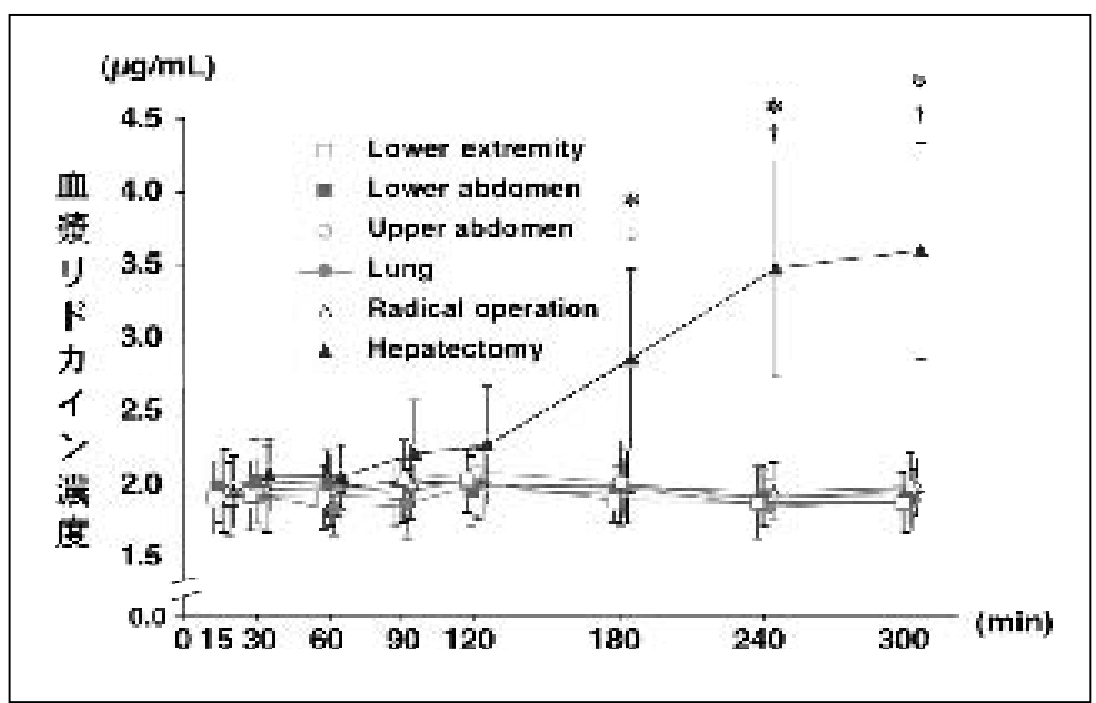

図5＼cjkstart各種手術における血中リドカイン濃度の変化

$1.5 \%$ リ゙カカインを $0.1 \mathrm{~m} l / \mathrm{kg}$ 注入後, $0.1 \mathrm{mg} / \mathrm{kg} / \mathrm{h}$ 持続硬膜外注入した場合 の血中濃度の変化. 手術部位および出血量にかかわらず, 肝切除術以外で は血中濃度の変化は少ないが, 肝切除術では時間の経過とともに血中濃度 の上昇が認められる。

Values are mean $\pm \mathrm{SD}$, 各群 $\mathrm{n}=12$

${ }^{*} P<0.01$ vs. 15 分, $\dagger P<0.01$ vs. other groups

〔文献30)より引用・改変〕

合は，筋弛緩作用はもちろん，知覚神経も広い範囲 を強く遮断する必要がある。全身麻酔と併用する場 合は，単独使用と同様に強い神経遮断が必要である かは硬膜外麻酔を主と考えるのか従と考えるのか, あるいは硬膜外麻酔にどれほどの神経遮断効果を期 待するかにより選択は異なると思われる。

2)術中麻酔か術後鎮痛か

手術中は知覚遮断に加え, 運動神経遮断あるいは 交感神経遮断効果を併せもつ局所麻酔薬および濃度 の選択が有利と思われる. 術後鎮痛はできるだけ知 覚神経遮断効果だけが期待できる薬剤および濃度を 選択するべきある。

3) 手術内容

例えば開腹術と体表手術では局所麻酔薬の種類と 濃度を変えるべきか等, 手術部位あるいは手術内容 が薬剤選択に影響を与えるかもしれない. 前述した ように投与した硬膜外腔の部位により無痛域の拡が
りは異なり ${ }^{29)}$ ，また肝切除では血中濃度が上昇する 可能性があり ${ }^{30)}$, 局所麻酔薬の容量や濃度を考慮す る必要がある。

4)持続投与か単回投与か 単回投与は多くの場合短時間の効果を期待してい ると考えられる。例えばペインクリニックでの使用 が考えられるが，この場合，長時間作用性局所麻酔 薬は避けるべきである。また，持続硬膜外投与が一 般的になった現在, 長時間作用性局所麻酔薬の必要 性は低いと思われる。

5)患者因子

高齢者では若年者に比べ，必要な容量と濃度はと もに減少する．前述のように妊娠も局所麻酔薬に対 する感受性が増すので, 妊娠初期より使用量は減量 すべきである。その他，局所麻酔薬の代謝に影響を 及ぼす肝臓疾患などでは，局所麻酔薬使用法に注意 を要する。 


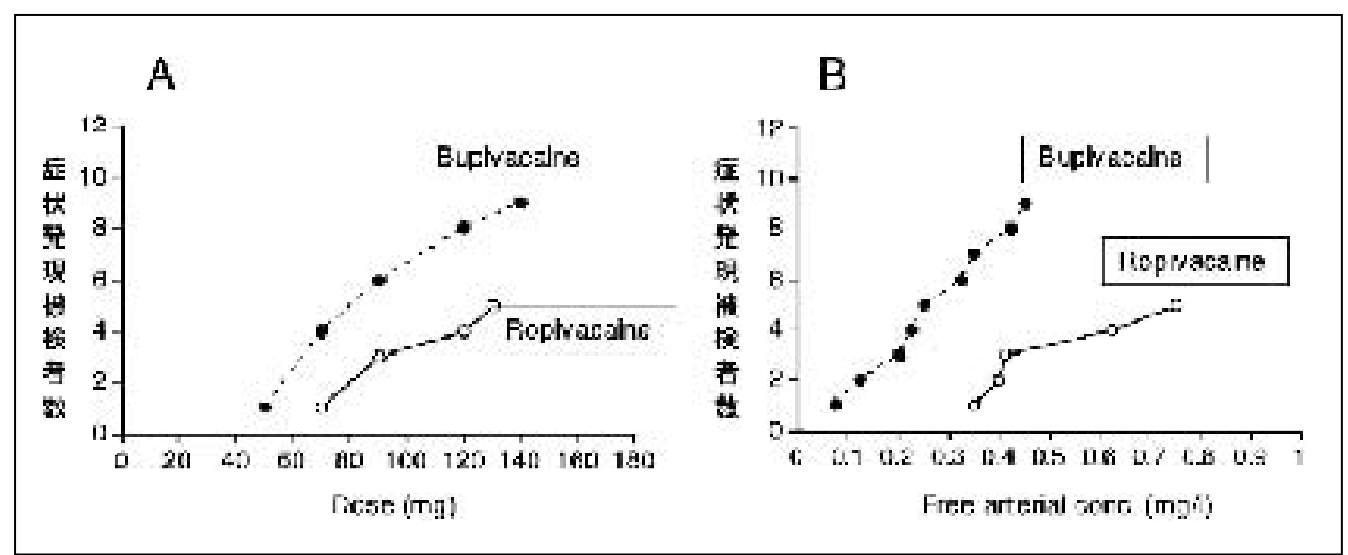

図6 筋攣縮を生じる局所麻酔薬の投与量 $(A)$ おび血中濃度 (B)

ある一定量を静注した場合，ブピバカインはロピバカインに比べて筋攣縮をきたす被検者が 明らかに多く $(\mathrm{A})$, 筋攣縮をきたした時点での血中濃度はブピバカインがロピバカインに比べ て明らかに低い.

〔文献 31)より引用・改変〕

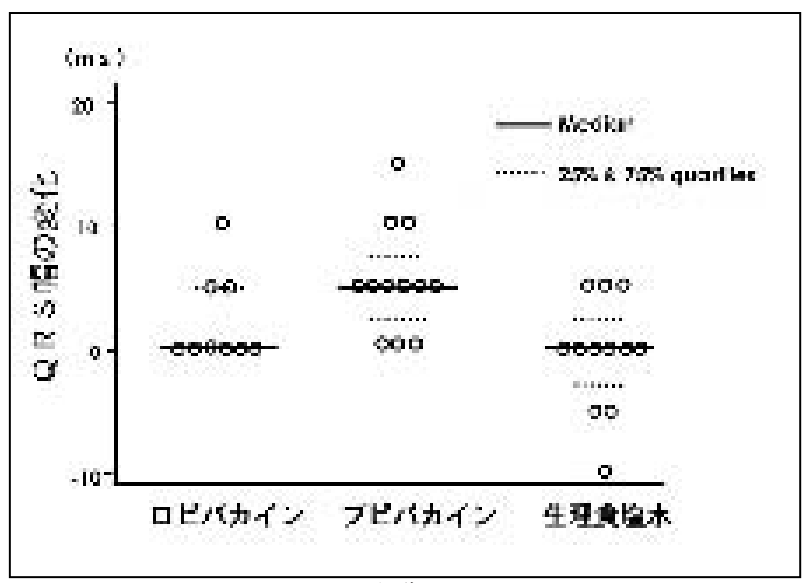

図 7 ロピバカインおよびブピバカインの不整脈惹起作 用の比較

ある一定量を静注した場合, ブピバカインはロピバ カインおよび生食に比べて有意に心電図上の QRS 幅 を延長させる $(P<0.05)$. QRS 幅の変化は薬剤投与前 の基準值と投与後の值の差で示す.

〔文献31)より引用・改変〕

\section{2. 局所麻酔薬選択の問題点：多種多様な薬刘は必要か}

1) 医療経済的観点

病院の経営的観点より, 在庫薬品をできるだけ減 らすことは最重要課題である。頻回に使用しないか ぎり, 同種同効薬として位置づけられる局所麻酔薬 を何種類も在庫としておくことは経営的には問題と なる。
2)局所麻酔薬の安全性

局所麻酔薬のもつ心毒性や神経毒性が問題となっ て, 安全性の高い新しい局所麻酔薬が登場している. あえて安全性に問題があるとされる薬剤を選択する には，明らかな医療上のメリットがある場合に限ら れる。例えば，アミド型の局所麻酔薬が悪性高熱の ために使用できないため，エステル型を使用する場 合などが考えられる。

3)薬剤使い分けによる煩雑さと事故

手術ごとの薬剤の変更や術中と術後の薬剤の変更 の煩雑さは, 薬剤取り違え事故の危険因子となりうる.

4)教育上の問題

数カ月でローテーションする現在の卒後研修シス テムでは，何種類もの局所麻酔薬をそれぞれの症例 や場面に合わせて使い分ける指導は適切でない。ク リニカルパスの考えからは，シンプルな薬剤投与が 安全かつ確実であると思われる。

\section{3. 新しい長時間作用性局所麻醐薬}

ロピバカインとレボブピバカインは，ほぼ同様の 性質の薬剤と考えられる。また, 安全性と知覚遮断 選択性の点から, 硬膜外注入薬剤の主流になると考 えられる。ロピバカインの中毒閾值が高いことは, 図 $6 \mathrm{~A}^{31)}$ に示すように, ブピバカインに比べて静注 


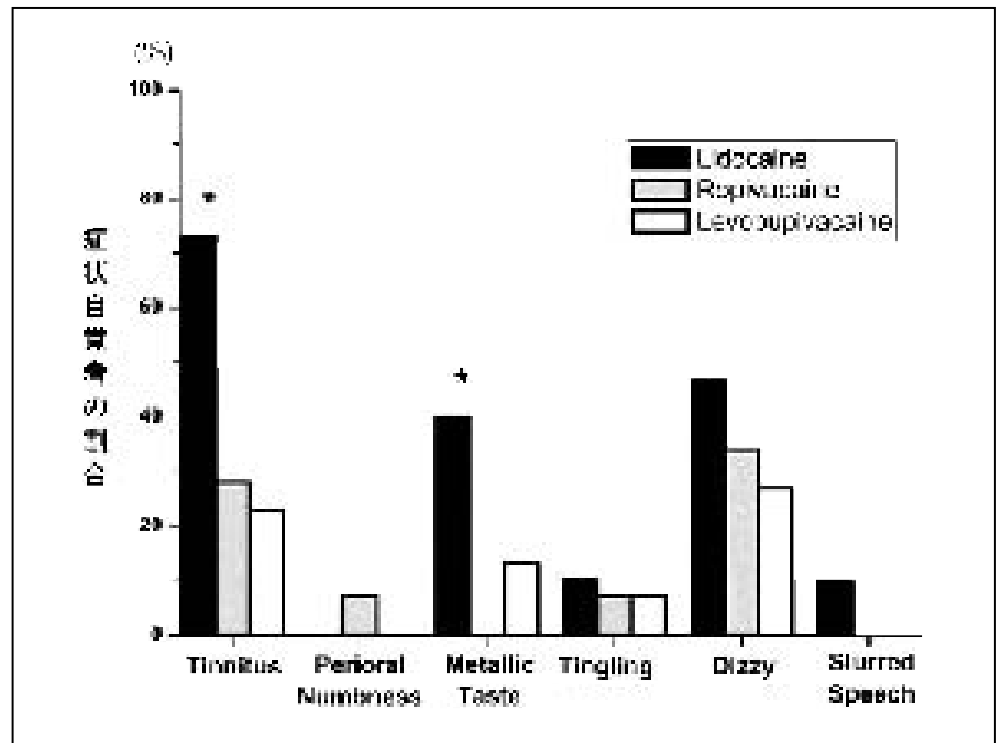

图8リドカイン, ロピバカインおよびレボブピバカインの中毒(中枢 神経)症状

テスト注入量の $2 \%$ リ゙カイン $5 \mathrm{ml}, 0.5 \%$ ロピバカイン $5 \mathrm{ml}$ あるいは $0.5 \%$ レ゙ブピバカイン $5 \mathrm{ml}$ を静注した場合, リドカインが他の薬剤 に比べて有意に中枢神経症状をきたしやすい.

量が増しても中毒症状の発現が少ないことからも明 らかである。また，図6Bでわかるように高い血中 濃度でも中毒症状が発現しにくい.ブピバカインで 問題となった心毒性に関しても，ロピバカインでは 不整脈惹起作用が弱いことが特徵である (図 7) ${ }^{31)}$. 特に全身麻酔と硬膜外麻酔の併用が日常化した今日 では，筋弛緩，睡眠，鎮痛を独立した薬剤あるいは 方法で達成することが一般的となっている。硬膜外 麻酔は鎮痛面の主役となり, 術後鎮痛にもそのまま 応用される。その意味においても，これらの新しい 局所麻酔薬は大きな位置を占める。

\section{4. テスト注入に使用すべき局所麻酔薬}

硬膜外麻酔のテスト注入には, 原則として, 作用 発現が速く効果の持続の短いものを用いるべきであ る。また，血管内注入を早期に発見するためにエピ ネフリンの添加が推奨されている。ロピバカイン, レボブピバカインは安全性では優れているが，テス ト注入の薬剤としては適していない ${ }^{32}$. 図8のよう
にテスト注入として一定量の局所麻酔薬が静注され た場合，リドカインでは静注のサインとしてさまざ まな中毒初期症状を呈し血管内注入の危険を喚起す るが，ロピバカインやレボブピバカインでは症状発 現が少なく，テスト注入の意味が薄れる。

\section{5. 臨床使用の実際}

現在，岡山大学では局所麻酔薬の在庫としてはリ ドカイン $(1 \%, 1 \%$ エピネフリン含有， $2 \%)$ とロピバ カイン $(0.2 \%, 0.75 \%)$ の 2 種類 5 品目のみである。以 下に岡山大学病院で使用している硬膜外麻酔におけ る局所麻酔薬の使用法の基本を概説する。

1)時間の調整

長時間の麻酔は持続カテーテルを使用すれば解決 するので，上記 2 種の局所麻酔薬で対応可能である. 外来などで短時間のブロックを期待する場合はリド カインを使用する.

2)テスト注入

安全面より必ず短時間作用性を使用すべきであ 
り，禁忌でないかぎりエピネフリン含有リドカイン を使用している。

3) 全身麻酔併用 術中は $0.2 \%$ ロピバカイン $20 \mathrm{~m} l+$ フェタニル 100 $\mu \mathrm{g}$ の溶液を適量初回注入した後は, $0.2 \%$ ロピバカ イン+フェンタニル $2.5 \sim 3 \mu \mathrm{g} / \mathrm{ml}$ を持続投与して いる. 術後は $0.15 \%$ ～ $0.2 \%$ ロピバカイン + フェンタ ニル $2 \sim 2.5 \mu \mathrm{g} / \mathrm{m} l$ を持続投与する.

4)硬膜外単独

一般手術では春髄くも膜下麻酔と硬膜外麻酔の併 用が原則で硬膜外麻酔単独使用はほとんどないが, 2\%リドカインあるいは $0.75 \%$ ロピバカインの使用で 対処する。ラジオ波焼却術などのインターベンショ ンでは $1.5 \%$ リ゙カインを, 無痛分娩には $0.15 \%$ ロピ バカインにそれぞれフェンタニルを適量添加したも のを基本としている.

\section{おわりに}

全身麻酔薬および麻酔法の変化に伴い, 硬膜外麻 酔を併用する麻酔法はさらに主流となり, 術後鎮痛 に期待される硬膜外ブロックの役割も増加すること が予想される．局所麻酔薬の種類の選択をはじめ, いかなる濃度を使用し, どのような添加薬剤といか なる割合で投与するかは, 安全性はもちろん, 周術 期医療の質にかかわる大きな課題と思われる.

\section{参考文献}

1) Albright GA : Cardiac arrest following regional anesthesia with etidocaine or bupivacaine. Anesthesiology $51: 285-287,1979$

2) Marx GF : Cardiotoxicity of local anesthetics-the plot thickens. Anesthesiology $60: 3-5,1984$

3) Luduena FP, Bogado EF, Tullar BF : Optical isomers of mepivacaine and bupivacaine. Arch Int Pharmacodyn Ther 200 : 359-369, 1972

4) Zaric D, Christiansen C, Pace NL, et al. : Transient neurologic symptoms after spinal anesthesia with lidocaine versus other local anesthetics : a systematic review of randomized, controlled trials. Anesth Analg
$100: 1811-1816,2005$

5) Feldman HS, Arthur GR, Covino BG : Comparative systemic toxicity of convulsant and supraconvulsant doses of intravenous ropivacaine, bupivacaine, and lidocaine in the conscious dog. Anesth Analg 69 : 794-801, 1989

6) Covino BG, Vassallo HG : Local Anesthetics : Mechanism of action and clinical use. Grune \& Stratton, New York, 1976

7) Strichartz GR, Berde CB : Local anesthetics, Miller's Anesthesia, 6th edition. Edited by Miller RD. Elsevier, Philadelphia, 2005

8) Johns RA, DiFazio CA, Longnecker DE : Lidocaine constricts or dilates rat arterioles in a dose-dependent manner. Anesthesiology $62: 141-144,1985$

9) Johns RA, Seyde WC, DiFazio CA, et al. : Dose-dependent effects of bupivacaine on rat muscle arterioles. Anesthesiology 65 : 186-191, 1986

10) Kopacz DJ, Carpenter RL, Mackey DC : Effect of ropivacaine on cutaneous capillary blood flow in pigs. Anesthesiology 71:69-74, 1989

11) McClure JH : Ropivacaine. Br J Anaesth $76: 300-307$, 1996

12) Hogan Q, Dotson R, Erickson S, et al. : Local anesthetic myotoxicity : a case and review. Anesthesiology 80 : 942-947, 1994

13) Cousins MJ, Bromage PR : Epidural nerve block, Neural Blockade in Clinical Anesthesia and Management of Pain. Edited by Cousins MJ, Bridenbaugh PO. JB Lippincott, Philadelphia, 1988

14) Erdemir HA, Soper LE, Sweet RB : Studies of factors affecting peridural anesthesia. Anesth Analg $44:$ 400, 1965

15) Yokoyama M, Hirakawa $M$, Goto $H$ : Effect of vasoconstrictive agents added to lidocaine on intravenous lidocaine-induced convulsions in rats. Anesthesiology 82 : 574-580, 1995

16) Concepcion M, Maddi R, Francis D, et al. : Vasoconstrictors in spinal anesthesia with tetracaine-a comparison of epinephrine and phenylephrine. Anesth Analg 63 : 134-138, 1984

17) Bokesch PM, Raymond SA, Strichartz GR : Dependence of lidocaine potency on $\mathrm{pH}$ and $\mathrm{PCO}$. Anesth Analg $66: 9-17,1987$

18) Wong K, Stricharts GR, Raymond SA : On the mechanisms of potentiation of local anesthetics by bicarbonate buffer : drug structure-activity studies on isolated peripheral nerve. Anesth Analg 76 : 131-143, 1993

19) Morison DH : A double-blind comparison of carbonat- 
ed lidocaine and lidocaine hydrochloride in epidural anaesthesia. Can Anaesth Soc J 28 : 387-389, 1981

20) Nickel P, Bromage PR, Sherrill DL : Comparison of hydrochloride and carbonated salts of lidocaine for epidural analgesia. Reg Anesth 11 : 62-67, 1986

21) Hilgier M : Alkalinization of bupivacaine for brachial plexus block. Reg Anesth 10 : 59-61, 1985

22) DiFazio CA, Carron H, Grosslight KR, et al. : Comparison of $\mathrm{pH}$-adjusted lidocaine solutions for epidural anesthesia. Anesth Analg 65 : 760-764, 1986

23) Bedder MD, Kozody R, Craig DB : Comparison of bupivacaine and alkalinized bupivacaine in brachial plexus anesthesia. Anesth Analg 67 : 48-52, 1988

24) de Beer DA, Thomas ML : Caudal additives in children -solutions or problems? Br J Anaesth 90 : 487-498, 2003

25) Cohen SE, Thurlow A : Comparison of a chloroprocaine-bupivacaine mixture with chloroprocaine and bupivacaine used individually for obstetric epidural analgesia. Anesthesiology 51 : 288-292, 1979

26) Kytta J, Heavner JE, Badgwell JM, et al. : Cardiovascular and central nervous system effects of co-administered lidocaine and bupivacaine in piglets. Reg Anesth
$16: 89-94,1991$

27) Bromage PR : Spread of analgesic solutions in the epidural space and their site of action: a statistical study. Br J Anaesth 34 : 161-178, 1962

28) Fagraeus L, Urban BJ, Bromage PR : Spread of epidural analgesia in early pregnancy. Anesthesiology 58 : 184-187, 1983

29) Yokoyama M, Hanazaki M, Fujii H, et al. : Correlation between the distribution of contrast medium and the extent of blockade during epidural anesthesia. Anesthesiology $100:$ 1504-1510, 2004

30) Yokoyama M, Mizobuchi S, Nagano O, et al. : The effects of epidural insertion site and surgical procedure on plasma lidocaine concentration. Anesth Analg $92: 470-475,2001$

31) Knudsen K, Beckman Suurkula M, Blomberg S, et al. : Central nervous and cardiovascular effects of i.v. infusions of ropivacaine, bupivacaine and placebo in volunteers. Br J Anaesth 78 : 507-514, 1997

32) Owen MD, Gautier P, Hood DD : Can ropivacaine and levobupivacaine be used as test doses during regional anesthesia? Anesthesiology $100: 922-925,2004$

\title{
Characteristics of Local Anesthetics for Epidural Anesthesia
}

\author{
Masataka YOKOYAMA \\ Department of Anesthesiology and Resuscitology, Okayama University Graduate School of Medicine, Dentistry \& Pharmaceutical Sciences
}

One should choose a drug from many kinds of local anesthetics depending on its use in epidural anesthesia. However, the first-line drug should be chosen based on safety because the disadvantages of some local anesthetics, such as cardiotoxicity and neurotoxicity, have become clear and new drugs have been developed recently. Many drugs are added for the purpose of increasing the potency of local anesthetics, but we should realize that few drugs can be used safely. Drug also should be chosen from the aspect of medical cost. The author recommends that a short-acting local anesthetic should be used as a test dose, and new long-acting local anesthetics should be used for anesthesia.

Key Words : Local anesthetics, Short-or long-acting, Epidural anesthesia

The Journal of Japan Society for Clinical Anesthesia Vol.27 No.5, 2007 